Pengaruh Metode Pengeringan dan Persentase Teh Kering - Adhamatika, dkk Jurnal Pangan dan Agroindustri Vol. 9 No.4: 196-207, Okt 2021

Diterima: 28/11/2020, Direview: 16/02/2021, Diterbitkan: 31/10/2021

\title{
PENGARUH METODE PENGERINGAN DAN PERSENTASE TEH KERING TERHADAP KARAKTERISTIK SEDUHAN TEH DAUN BIDARA (Ziziphus mauritiana L.)
}

\section{The Effect of Drying Method and Percentage of Dried Tea on The Characteristics Bidara Leaves Tea (Ziziphus mauritiana L.)}

\author{
Adhima Adhamatika*, Erni Sofia Murtini \\ Jurusan Teknologi Hasil Pertanian, FTP Universitas Brawijaya Malang \\ JI. Veteran, Malang 65145 \\ *Penulis Korespondensi, Email: adhimaadhamatika67@gmail.com
}

\begin{abstract}
ABSTRAK
Bidara merupakan tanaman tradisonal yang daunnya mengandung tinggi polifenol sehingga berpotensi untuk dikembangkan menjadi produk teh herbal. Pengeringan daun bidara sangat berpengaruh terhadap kualitas rasa, warna, dan aroma teh. Penelitian ini bertujuan untuk mengkaji pengaruh - pengaruh yang dapat ditimbulkan dari metode pengeringan dan persentase teh kering terhadap karakteristik sampel seduhan teh bidara yang dibuat pada penelitian ini. Desain penelitian digunakan RAKF 2 faktor. Faktor pertama meliputi metode pengeringan yang sering digunakan dalam pengeringan teh yaitu pengeringan kabinet, sangrai, dan sinar matahari. Faktor 2 meliputi persentase penggunaan teh kering yaitu $1 \%, 3 \%$, dan $5 \%$ dengan masing-masing 3 kali ulangan. Respon yang diuji meliputi warna, $\mathrm{pH}$, fenol, flavonoid, aktivitas antioksidan, tanin, dan uji organoleptik yang dilakukan dengan uji hedonik. Penelitian ini menunjukkan bahwa teh daun bidara terbaik dihasilkan dari pengeringan sinar matahari dengan presentase penggunaan teh kering sebesar $5 \%$ dengan nilai fenol, flavonoid, tanin, antioksidan, dan skor hedonik paling optimal.
\end{abstract}

Kata kunci: Bidara, Daun, Metod pengeringan, Presentase teh kering, Teh

\section{ABSTRACT}

Bidara is traditional plant that is their leaves contain high in polyphenols so that it has potential to be developed into herbal tea product. Bidara leaves drying greatly affects the quality of taste, color, and aroma of tea. The objectivities of this study was to see the drying method and brewed dry tea percentage effects on the bidara leaves tea characteristics. Randomized Block Design with 2 factors was used for the design of this research. First factor is the drying method includes cabinet, roasted, and sun dried. Second factor is the percentage of dried tea used includes 1\%, 3\%, and 5\% with each repeated 3 times. Responses analyzed were color, $\mathrm{pH}$, phenol, flavonoid, antioxidant activity, tannin, and organoleptic test with hedonic test. The results showed that the best bidara leaves tea was produces from sun drying with percentage of dried tea $5 \%$ with the optimum rate in phenols, flavonoids, tannins, antioxidant activity, and hedonic test score.

Keywords: Bidara, Drying method, , Leaves, Percentage of dried tea, Tea

\section{PENDAHULUAN}

Konsumsi teh dunia tahun 2015 berkisar 4.84 juta ton dan Indonesia merupakan negara produsen teh terbesar ke 7 dunia dengan produksi teh mencapai 152.7 ribu ton pada 
tahun 2013 (FAO, 2015). Teh yang sering dikonsumsi di Indonesia umumnya berasal dari Camelia sinensis L., yaitu tanaman teh yang sering dikembangkan untuk diseduh daunnya. Saat ini teh juga dipandang sebagai produk fungsional yang memiliki dampak positif bagi tubuh. Tren tersebut mendorong adanya inovasi teh yang bisa dikembangkan dari tanaman selain the pada umumnya. Bahan baku yang dapat dikembangkan menjadi produk olahan teh yaitu daun bidara yang kaya akan kandungan fungsional baik bagi tubuh.

Bidara sering ditemui dalam bentuk pohon kecil atau semak dengan beberapa duri. Tanaman ini digolongkan dalam family Rhammaceace yang tumbuh subur di beberapa wilayah dataran rendah Indonesia (Orwa et al., 2009). Berdasarkan uji kualitatif El-Ishaq \& Nangere (2016), didapatkan daun bidara mengandung beberapa senyawa fenolik. Beberapa golongan flavonoid seperti tanin, alkaloid, dan saponin terkandung dalam daun bidara yang masih segar. Menurut Yahia et al., (2020), ekstrak daun bidara dapat mengandung total fenol sebesar $532.95 \mathrm{mg} \mathrm{GAE} / 100$ gram. Dengan adanya senyawa fenolik tersebut, daun bidara merupakan bahan baku potensial untuk dikembangkan sebagai bahan teh dengan tujuan meningkatkan diversifikasi produk teh di Indonesia.

Produk olahan daun bidara sudah banyak dipasarkan di Indonesia, namun untuk saat ini daun bidara dimanfaatkan hanya sebai pengusir roh jahat dalam kepercayaan agama. Untuk produk teh daun bidara sendiri sejatinya juga sudah banyak, namun peminatnya masih sangat minim. Banyak kekeruangan dari teh daun bidara yang menyebabkan teh tidak disukai oleh konsumen, meliputi rasa pahit, aromanya kurang kuat serta warna teh kurang pekat. Menurut Taufik et al., (2016), aroma dan rasa yang spesifik dan khas pada teh dapat dibentuk melalui pengeringan yang sesuai. Pengeringan mampu menurunkan kadar air serta meningkatkan konsentrasi komponen fenolik pembentuk warna, rasa, dan aroma pada teh. Pengeringan daun teh yang sering digunakan yaitu pengeringan kabinet, sangrai, dan penjemuran sinar matahari. Warna teh yang terbentuk sangatlah dipengaruhi oleh jumlah teh kering yang akan diseduh. Hal ini mendorong dilakukan penelitian ini guna dapat melihat pengaruh yang timbul pada karakteristik seduhan teh daun bidara dengan variasi metode pengeringan dan persentase teh kering yang digunakan. Perlakuan terbaik juga akan ditentukan dengan mengukur respon kualitas teh yang dihasilkan meliputi rasa, warna, aroma, hingga kandungan senyawa fenolik didalamnya.

\section{BAHAN DAN METODE}

\section{Bahan}

Bahan baku utama pada penelitian ini yaitu daun bidara jenis arab dengan nama latin Ziziphus mauritiana L. dengan kondisi yang masih segar dan memiliki warna hijau cerah (tidak rusak). Daun bidara pada penelitian ini dapat diperoleh di daerah pantai Mayangan, Kota Probolinggo. Air yang digunakan untuk menyeduh teh daun bidara kering memiliki pH 6.8. Bahan analisis meliputi aquades (Hydrobatt), metanol, DPPH, Folin, $\mathrm{NaNO}_{2}, \mathrm{NaOH}, \mathrm{AlCl}_{3}, \mathrm{Na}_{2} \mathrm{CO}_{3}$, standar galat, asam tanat, dan quersetin sebagai standar analisis.

\section{Alat}

Alat - alat yang dibutuhkan meliputi pengering kabinet (Lokal,Indonesia), kompor gas RI-603 (Rinnai, Japan), regulator, gunting / pisau, LPG, penampan untuk pengeringan sinar matahari, penyaring, timbangan digital, gelas ukur, corong plastik, loyang / wadah, serta wajan sebagai media sangrai. Alat untuk analisis meliputi $\mathrm{pH}$ meter, color reader (KonicaMinolta, Japan), timbangan analitik (Denver-Instrument M-310), oven listrik untuk mengukur kadar air, desikator (Nucerite), spektrofotometer (Spectro-20D-Pluss), glassware, vortex (Lw-scientific) spatula, cawan porselen.

\section{Desain Penelitian}

Desain penelitian dipilih yaitu dengan penggunaan Rancangan Acak Kelompok 2 Faktor atau RAKF, dimana faktor pertama yaitu metode pengeringan (kabinet, sangrai, dan 
sinar matahari). Sedangkan faktor kedua digunakan persentase penggunaan teh kering yang diseduh meliputi $1 \%, 3 \%$, dan $5 \%$.

\section{Tahapan Penelitian}

1. Pembuatan Teh Kering dari Daun Bidara (Rohdiana, 2015)

Bahan baku bidara dengan warna daun hijau diambil dari wilayah sekitar Pelabuhan Kota Probolinggo, Jawa Timur. Daun dibersihkan dengan air mengalir, kemudian dianginkan untuk menghilangkan air pada daun. Daun diletakkan diatas tray untuk dilakukan pelayuan pada kondisi ruang dengan suhu $\pm 27^{\circ} \mathrm{C}$ dengan lama waktu 24 jam. Daun bidara yang sudah layu dipotong dan diperkecil ukurannya menggunakan gunting / pisau foodgrade ukuran sekitar $0.5 \times 1 \mathrm{~cm}$ secara seragam. Kemudian dikeringkan menggunakan 3 jenis metode, pengeringan kabinet $60^{\circ} \mathrm{C} 4 \mathrm{jam}$, penyangraian menggunakan wajan suhu $95^{\circ} \mathrm{C} 5$ menit, dan pengeringan sinar matahari suhu sekitar $35^{\circ} \mathrm{C} 8$ jam. Daun bidara kering disimpan dalam wadah tertutup untuk dipersiapkan ke tahap selanjutnya yaitu penyeduhan daun bidara kering menjadi teh bidara.

\section{Pembuatan Seduhan Teh Daun Bidara (Rohdiana, 2015)}

Ditimbang daun bidara kering berdasarkan perlakuan yaitu $1 \%$, 3\%, dan $5 \%$ dari berat air pelarut atau media penyeduh yang digunakan. Daun bidara kering ditimbang dengan berat masing-masing 1, 3, dan 5 gram lalu diseduh dengan air panas $100 \mathrm{~mL}$. Penyeduhan dilakukan selama 5 menit di dalam panci. Ampas dari daun bidara yang tidak larut dalam air seduhan disaring dan dipisahkan menggunakan saringan. Teh daun bidara disimpan dalam cup plastik dan ditutup menggunakan cup sealer untuk segera dianalisis.

\section{Metode}

Pengujian dilakukan dengan pengulangan 3 kali dan didapatkan 27 satuan percobaan. Data-data yang didapatkan akan diuji menggunakan ANOVA $\alpha=0.05$. Apabila didapatkan faktor berpengaruh nyata terhadap respon yang diuji, maka perlu dilakukan uji lanjut untuk melihat adanya perbedaan nilai antara faktor satu dengan yang lainnya. Uji DMRT (Duncan Multiple Range Test) dipilih untuk mengetahui beda nyata yang ditunjukan oleh adanya notasi di akhir angka tiap perlakuan atau sampel, sehingga akan didapatkan notasi beda nyata pada data hasil penelitian yang dilakukan. Perlakuan terbaik dipilih dan diukur dengan metode Multiple Attribute Zeleny (Zeleny, 1982).

\section{Prosedur Analisis}

\section{a. Analisis Fisik dan Kimia}

Kadar air dari daun bidara segar dan kering ditentukan menggunakan analisis standar dari AACC(2000) dengan metode gravimetri. Warna dari daun bidara segar, kering, dan air seduhan teh daun bidara diukur menggunakan color reader CR-300 chroma-meter (Minolta, Japan). Data warna dilaporkan dalam kecerahan dengan lambang $L^{*}$, kemerahan dengan lambang $a^{*}$, serta kekuningan yang dilambangkan $b^{*}$. $L^{*}$ melambangkan nilai kecerahan dari sampel yang diuji. Nilai $a^{*}$ positif melambangkan warna yang semakin merah, sedangkan nilai $a^{\star}$ negatif melambangkan warna yang semakin hijau pada sampel. Nilai $b^{*}$ positif melambangkan warna yang semakin kuning, sedangkan nilai $b^{*}$ negatif melambangkan warna yang semakin biru. $\mathrm{pH}$ dari sampel diukur menggunakan $\mathrm{pH}$ meter.

\section{b. Analisis Senyawa Fungsional dan Aktivitas Antioksidan}

Analisis komponen fungsional yang dilakukan meliputi analisis fenol, flavonoid, tanin, hingga aktivitas antioksidan. Total fenol ditentukan berdasarkan metode (Matthäus, 2002) dengan modifikasi. Total fenol pada sampel ditentukan menggunakan metode spektrofotometer. $0.5 \mathrm{~mL}$ air seduhan teh daun bidara ditambahkan dengan $2.5 \mathrm{~mL} 10 \%$ Folin Ciocalteau dan $2 \mathrm{~mL} 7.5 \% \quad \mathrm{Na}_{2} \mathrm{CO}_{3}$ pada tabung reaksi. Kemudian diinkubasi pada tempat yang tertutup dengan lama waktu 30 menit. Absorbansi sampel diukur nilainya 
menggunakan panjang gelombang $756 \mathrm{~nm}$ dengan spektrofotometer. Konsentrasi total fenol ditentukan menggunakan persamaan dari standar asam galat.

Total flavonoid pada sampel ditentukan dengan menggunakan metode dari Li et al. (2007). Total flavonoid pada sampel ditentukan dengan menggunakan metode spektrofotometri. $1 \mathrm{~mL}$ sampel teh daun bidara ditambahkan $3 \mathrm{~mL}$ akuades dan $0.3 \mathrm{~mL}$ $\mathrm{NaNO}_{2}$. Dilakukan inkubasi pada tempat gelap dengan lama waktu 6 menit. Selanjutnya campuran dimasukkan $4 \mathrm{~mL}$ larutan $\mathrm{NaOH}$ konsentrasi $1 \mathrm{M}$. Ditambahkan akuades sebagai pelarut hingga volumenya menjadi $10 \mathrm{~mL}$. Dilakukan inkubasi kembali selama 15 menit. Nilai absorbansi sampel diukur menggunakan panjang gelombang $502 \mathrm{~nm}$ dengan spektrofotometer. Konsentrasi total flavonoid ditentukan menggunakan persamaan hasil standar kuersertin.

Kadar tanin ditentukan menggunakan metode AOAC (1995). Kadar tanin pada sampel ditentukan menggunakan spektrofotometri. $0,1 \mathrm{~mL}$ sampel direaksikan dengan 7.5 $\mathrm{mL}$ akuades serta $0.5 \mathrm{~mL}$ Folin Ciocalteau pekat, lalu sampel diinkubasi pada tempat gelap dengan lama waktu 5 menit. $1 \mathrm{~mL}$ larutan $35 \% \quad \mathrm{Na}_{2} \mathrm{CO}_{3}$ ditambahkan dan ditambahkan akuades hingga volume menjadi $10 \mathrm{~mL}$. Diinkbasi selama 30 menit. Absorbansi diukur menggunakan spektrofotometer dengan konsentrasi tanin ditentukan melalui perhitungan persamaan standar asam tanat yang digunakan.

Aktivitas antioksidan diukur menggunakan metode Blois (1958) dengan beberapa modifikasi. Aktivitas antioksidan diuji dengan menurunkan radikal DPPH pada metanol yang akan menurunkan absorbansi pada panjang gelombang $517 \mathrm{~nm} .4 \mathrm{~mL}$ DPPH dalam metanol $0.1 \mathrm{mM}$ ditambahkan $1 \mathrm{~mL}$ sampel. Dilakukan inkubasi selama 20 menit pada tempat gelap. Kemudian absorbansi diukur dan ditentukan nilai aktivitas antioksidan pada sampel menggunakan rumus perhitungan sebagai:

$$
\text { Aktivitas Antioksidan (\%) }=100 \% \times(1-\mathrm{A} / \mathrm{B})
$$

Dimana A merupakan nilai absorbansi sampel, sedangkan B merupakan nilai absorbansi kontrol yang hanya berisikan metanol.

\section{c. Analisis Organoleptik}

Analisis organoleptik pada penelitian ini dilakukan dengan menggunakan metode uji hedonik. Analisis organoleptik sendiri dilakukan untuk memberikan skor pada sampel yang disajikan. Sehingga dapat diketahui tingkat penerimaan dan kesukaan panelis yang mewakilkan konsumen secara umum terhadap teh daun bidara yang dibuat. Parameter yang diuji meliputi aroma, warna, hingga rasa seduhan teh yang disajikan. Sebanyak 40 orang panelis tidak terlatih dipilih dari mahasiswa Jurusan THP, FTP, Universitas Brawijaya secara acak. Panelis diminta untuk menuliskan tanggapannya terkait aroma, warna, dan rasa dari teh yang disajikan sebanyak 9 sampel. Skala penilaian hedonik yang dipilih untuk digunakan pada uji hedonik ini hanya skor 1-5, dengan keterangan bahwa 1 = sangat tidak disukai, 2 = tidak disukai, 3 = netral, 4 = suka, dan 5 = sangat suka. Jumlah panelis digunakan sebagai ulangan.

\section{HASIL DAN PEMBAHASAN}

\section{Karakteristik Daun Bidara Segar dan Teh Daun Bidara Kering}

Analisis pertama yang dilakukan dalam penelitian ini yaitu analisis karakteristik daun bidara segar dan daun yang telah diolah menjadi teh keringnya dari hasil 3 metode pengeringan berbeda (kabinet, sangrai, dan sinar matahari). Respon yang diuji pada analisis bahan baku meiputi kadar air, kandungan senyawa fenolik, serta aktivitas antioksidan dalam daun segar dan kering. Didapatkan adanya perubahan respon terkait perubahan yang terjadi dari daun bidara segar menjadi bentuk teh kering. Hasil analisis karakteristik daun bidara sehar dan teh keringnya disajikan pada Tabel 1. 
Tabel 1. Hasil Analisis Karalteristik Daun Bidara Segar dan Teh Daun Bidara Kering

\begin{tabular}{|c|c|c|c|c|}
\hline \multirow[b]{2}{*}{ Parameter } & \multirow[b]{2}{*}{$\begin{array}{l}\text { Bidara } \\
\text { Segar }\end{array}$} & \multicolumn{3}{|c|}{ Teh Bidara Kering } \\
\hline & & $\begin{array}{c}\text { Pengeringan } \\
\text { Kabinet }\end{array}$ & Sangrai & Sinar-Matahari \\
\hline Kadar Air (\%) & $60.01 \pm 0.34$ & $6.12 \pm 0.07^{b}$ & $5.86 \pm 0.02^{c}$ & $6.99 \pm 0.07^{a}$ \\
\hline Total Fenol $(\mathrm{mg} / \mathrm{g})$ & $61.25 \pm 1.67$ & $62.26 \pm 1.32^{\mathrm{b}}$ & $64.55 \pm 0.54^{b}$ & $71.00 \pm 1.90^{a}$ \\
\hline Total Flavonoid $(\mathrm{mg} / \mathrm{g})$ & $61.16 \pm 2.90$ & $61.26 \pm 1.08^{c}$ & $63.65 \pm 0.23^{b}$ & $67.75 \pm 0.62^{a}$ \\
\hline Kadar Tanin $(\mathrm{mg} / \mathrm{g})$ & $19.06 \pm 0.08$ & $13.28 \pm 0.71^{c}$ & $14.50 \pm 0.33^{b}$ & $16.90 \pm 0.79^{a}$ \\
\hline Aktivitas Antioksidan (\%) & $77.11 \pm 0.38$ & $77.88 \pm 0.95^{c}$ & $79.89 \pm 0.61^{b}$ & $83.62 \pm 0.33^{a}$ \\
\hline
\end{tabular}

Keterangan: 1. Data disertai dengan standar deviasi hasil dari rerata 3 kali ulangan.

2. Angka disertai huruf berbeda menandakan perbedaan nyata $\alpha=0.05$ ).

Hasil analisis karakteristik bahan baku menunjukkan adanya penurunan kadar air setelah dilakukan proses pengolahan dari daun bidara segar hingga menjadi bentuk teh kering. Hasil ini dibandingkan dengan standar untuk teh hijau yang berlaku di Indonesia yaitu SNI. Perbandingan dengan teh hijau dipilih karena pengolahan teh daun bidara dan teh hijau sama. Standar yang ada pada SNI 3945:2016 menyatakan bahwa kadar air maksimal untuk teh hijau di Indonesia yaitu $8 \%$. Hasil ini sudah cukup menunjukkan bahwa teh daun bidara kering hasil 3 metode pengeringan berbeda yang digunakan sudah sesuai dan memenuhi standar yang ada untuk teh hijau di Indonesia.

Total fenol dan flavonoid mengalami sedikit kenaikan setelah dilakukan proses pengolahan daun segar menjadi kering. Namun jumlahnya tidak sebanding dengan penurunan kadar air yang terjadi. Sedangkan terdapat penurunan nilai kandungan tanin dalam daun bidara dalam bentuk segar menjadi bentuk kering. Aktivitas antioksidan daun bidara cenderung meningkat setelah daun diolah menjadi bentuk teh kering. Hasil analisis ini menunjukkan bawa metode pengeringan dengan menggunakan sinar matahari lebih dapat mempertahankan komponen fenolik dan antioksidan dengan nilai tinggi dibandingkan sangrai dan kabinet. Menurut Harjanti et al., (2003) senyawa fenolik dapat mengalami kersusakan struktur akibat panas yang berlebih dengan suhu diatas $85^{\circ} \mathrm{C}$.

Menurut Taufik et al., (2016) pengeringan dengan menggunakan suhu tinggi mampu menurunkan kadar air paling tinggi dalam proses pembuatan teh. Kadar air yang rendah menyebabkan terjadinya peningkatan beberapa kadar komponen lain pada teh kering seperti polifenol. Dengan meningkatnya polifenol, maka daun bidara memiliki kemampuan yang semakin tinggi pula dalam menangkal radikal atau oksidan, sehingga nilai aktivitas antioksidan pada sampel juga akan meningkat. Pengeringan teh dengan menggunakan suhu tinggi dapat menyebabkan kerusakan struktur dalam senyawa polifenol yang dapat menurunkan sifat fungsional alaminya. Sehingga dibutuhkan jenis pengeringan yang sesuai sehingga didapatkan teh bidara dengan kualitas terbaik.

\section{Karakteristik Warna dan pH Seduhan Teh Daun Bidara}

Secara umum perlakuan metode pengeringan dan persentase penggunaan teh kering memberikan pengaruh signifikan pada karakteristik fisik beruapa parameter warna $\left(L^{*}, a^{*}, \& b^{*}\right)$ dan $\mathrm{pH}$ seduhan teh daun bidara.

Tabel 2. Karakteristik Fisik dan pH Seduhan Teh Daun Bidara

\begin{tabular}{cccccc}
\hline \multicolumn{2}{c}{ Sampel } & $\mathrm{L}^{*}$ & $\mathrm{a}^{*}$ & $\mathrm{~b}^{*}$ & $\mathrm{pH}$ \\
\hline \multirow{3}{*}{ Kabinet } & $1 \%$ & $34.00 \pm 0.54^{\mathrm{a}}$ & $2.12 \pm 0.17^{\mathrm{e}}$ & $14.17 \pm 1.41^{\mathrm{a}}$ & $6.43 \pm 0.06^{\mathrm{a}}$ \\
& $3 \%$ & $30.24 \pm 0.80^{\mathrm{bc}}$ & $2.89 \pm 0.33^{\mathrm{cd}}$ & $11.05 \pm 0.63^{\mathrm{b}}$ & $5.97 \pm 0.15^{\mathrm{b}}$ \\
& $5 \%$ & $28.44 \pm 0.42^{\mathrm{de}}$ & $3.41 \pm 0.03^{\mathrm{abc}}$ & $7.41 \pm 1.12^{\mathrm{cd}}$ & $5.47 \pm 0.12^{\mathrm{de}}$ \\
\hline \multirow{3}{*}{ Sangrai } & $1 \%$ & $31.45 \pm 0.23^{\mathrm{b}}$ & $2.44 \pm 0.22^{\mathrm{de}}$ & $11.13 \pm 0.55^{\mathrm{b}}$ & $6.07 \pm 0.12^{\mathrm{b}}$ \\
& $3 \%$ & $28.56 \pm 0.80^{\text {de }}$ & $3.06 \pm 0.02^{\mathrm{bc}}$ & $8.58 \pm 0.14^{\mathrm{c}}$ & $5.60 \pm 0.10^{\mathrm{cd}}$ \\
& $5 \%$ & $27.67 \pm 0.47^{\text {ef }}$ & $3.54 \pm 0.19^{\mathrm{ab}}$ & $7.09 \pm 0.20^{\mathrm{cd}}$ & $5.40 \pm 0.10^{\text {de }}$ \\
\hline
\end{tabular}


Pengaruh Metode Pengeringan dan Persentase Teh Kering - Adhamatika, dkk Jurnal Pangan dan Agroindustri Vol. 9 No.4: 196-207, Okt 2021

\begin{tabular}{cccccc} 
& $1 \%$ & $29.50 \pm 0.26^{\mathrm{cd}}$ & $2.52 \pm 0.20^{\mathrm{de}}$ & $8.02 \pm 0.80^{\text {cd }}$ & $5.90 \pm 0.10^{\mathrm{bc}}$ \\
Sinar & $3 \%$ & $27.75 \pm 0.27^{\mathrm{ef}}$ & $3.15 \pm 0.17^{\mathrm{abc}}$ & $6.50 \pm 0.43^{\mathrm{d}}$ & $5.43 \pm 0.06^{\mathrm{de}}$ \\
Matahari & $5 \%$ & $26.36 \pm 0.32^{\mathrm{f}}$ & $3.66 \pm 0.19^{\mathrm{a}}$ & $4.04 \pm 0.39^{\mathrm{e}}$ & $5.17 \pm 0.15^{\mathrm{e}}$ \\
\hline
\end{tabular}

Keterangan: 1. Data disertai dengan standar deviasi hasil dari rerata 3 kali ulangan.

2. Angka disertai huruf berbeda menandakan perbedaan nyata $\alpha=0.05$ ).

\subsection{Kecerahan $\left(L^{*}\right)$}

Tingkat kecerahan sampel seduhan teh yang dibuat pada penelitian ini memiliki nilai berkisar antara 26.36 - 34.00. Seduhan teh daun bidara yang dibuat menggunakan metode pengeringan sinar matahari memiliki warna yang paling pekat dan nilai kecerahan paling rendah, sedangkan seduhan teh bidara dengan pengering kabinet mampu menghasilkan seduhan dengan warna yang paling cerah. Hasil ini ditunjukkan dengan nilai kecerahan paling tinggi ada pada sampel pengeringan kabinet dan paling rendah pada sampel pengeringan sinar matahari. Pengeringan dengan menggunakan sinar matahari memiliki suhu tidak stabil dan relatif rendah dibandingkan jenis pengeringan lainnya yaitu $+/-27^{\circ} \mathrm{C}$. Enzim yang berperan dalam proses oksidasi alami polifenol pada daun yaitu polifenol oksidase masih aktif apabila suhu tidak terlalu tinggi, kemudian akan mampu berperan sebagai oksidator untuk beberapa komponen fenolik dan akan menghasilkan senyawa turunan warna seperti thearubigin dan theaflavin (Yulianto et al., 2006).

Persentase penggunaan teh kering dalam jumlah tinggi mampu membentuk warna seduhan yang semakin pekat serta nilai $L^{*}$ semakin rendah. Peningkatan persentase penggunaan teh kering yang digunakan dalam proses penyeduhan maka akan meningkatkan beberapa senyawa pembentuk warna seperti thearubigin dan theaflavin yang terlarut dalam air seduhan saat proses penyeduhan. Klorofil yang terdegradasi juga akan semakin banyak pada teh, sehingga warna yang dihasilkan teh akan didominasi hasil warna feofitin sebagai senyawa derivat dari klorofil yang berwarna kuning kecoklatan (Schwartz et al., 2017).

\subsection{Kemerahan $\left(a^{*}\right)$}

Tingkat kemerahan sampel seduhan teh daun bidara yang dibuat pada pengujian ini memiliki nilai berkisar antara 2.12 - 3.66. Seduhan teh daun bidara yang dibuat menggunakan metode pengeringan sinar matahari memiliki warna merah pekat yang didukung juga dengan nilai kemerahan tertinggi dibandingkan yang lain, sedangkan seduhan teh yang dibuat menggunakan metode pengeringan kabinet didapatkan warna yang cerah serta nilai kemerahan $\left(a^{*}\right)$ terendah dibandingkan sangrai dan sinar matahari. Pusat Penelitian dan Pengembangan Perkebunan (2013) menyatakan bahwa beberapa senyawa polifenol seperti katekin dapat mengalami oksidasi dan menghasilkan senyawa turunan warna seperti thearubigin serta theaflavin yang memberikan warna pada air seduhan pada proses penyeduhan teh. Menurut penelitian Yahia et al., (2020) daun bidara mengandung epikatekin sebanyak $46.49 \mu \mathrm{g} / \mathrm{g}$.

Persentase penggunaan teh kering yang semakin tinggi akan menyebabkan warna teh menjadi lebih merah dengan nilai $a^{*}$ yang meningkat seiring penambahan teh kering yang digunakan. Semakin tinggi persentase penggunaan teh kering yang dipilih akan menyebabkan semakin banyak juga senyawa pembentuk warna yang ikut terlarut pada air seduhan dalam penyeduhan teh daun bidara. Peningkatan kemerahan juga dapat disebabkan adanya reaksi epimerisasi pada klorofil selama pemanasan. Klorofil akan berubah menjadi feofitin hingga firofeofitin apabila teroksidasi lebih lanjut menyebabkan warna hijau berubah menjadi coklat (Schwartz et al., 2017).

\subsection{Kekuningan $\left(b^{*}\right)$}

Tingkat kekuningan sampel seduhan teh bidara yang dibuat pada penelitian ini berkisar antara $4.04-14.17$. Seduhan teh hasil pengeringan kabinet memiliki warna yang paling cerah, sehingga didapatkan nilai kekuningan $\left(b^{*}\right)$ seduhan teh tersebut paling tinggi dibandingkan metode pengeringan lain yang digunakan. Suhu yang digunakan pada metode 
pengering kabinet relatif tidak terlalu tinggi, suhu yang digunakan yaitu $60^{\circ} \mathrm{C}$ yang mampu menginaktivasi beberapa enzim oksidasi alami pada daun seperti polifenol-oksidase. Shabri \& Rohdiana (2016) menjelaskan bahwa enzim polifenol oksidase akan bertanggung jawab membentuk warna kuning kecoklatan akibat hasil oksidasi enzimatis dari komponen fenol dalam seduhan teh.

Persentase penggunaan teh kering yang semakin banyak mampu memberikan warna seduhan teh gelap dan pekat, serta nilai kekuningan $\left(b^{*}\right)$ yang rendah. Hasil tersebut dikarenakan penggunaan persentase teh kering yang semakin banyak akan meningkatkan jumlah klorofil yang terdegradasi akibat panas menjadi komponen derivatisasi, seperti feofitin yang disebabkan oleh hilangnya ion $\mathrm{Mg}^{2+}$ pada cincin forfirin selama pemanasan. Hasil dari degradasi klorofil akan menurunkan intensitas warna hijau dari klorofil dan perlahan akan berubah menjadi kuning kecoklatan yang merupakan warna dari feofitin (Ferruzzi \& Blakeslee, 2007).

\section{$2.4 \mathrm{pH}$}

Nilai $\mathrm{pH}$ seduhan teh bidara pada penelitian ini didapatkan sebesar $5.17-6.43$. Hasil uji ANOVA didapatkan jika kedua faktor meliputi metode pengeringan dan persentase penggunaan teh kering memberikan pemgaruh signifikan pada nilai $\mathrm{pH}$ dari seduhan teh yang dihasilkan. Pengeringan kabinet menggunakan suhu yang relatif sesuai atau tidak terlalu rendah maupun tinggi suhu $60^{\circ} \mathrm{C}$ dengan lama waktu 4 jam mampu menghasilkan nilai $\mathrm{pH}$ tertinggi pada sampel yang dibuat daripada metode pengeringan sinar matahari ataupun sangrai. Seduhan teh yang dibuat dengan menggunakan metode sinar matahari cenderung memiliki pH yang rendah, bahkan paling rendah dibandingkan sangrai ataupun kabinet. Menurut Shabri \& Maulana (2017) menyatakan proses oksidasi komponen polifenol akibat kadar air yang tinggi dapat menghasilkan senyawa turunan yang bersifat asam.

Persentase penggunaan teh kering yang semakin tinggi akan menurunkan $\mathrm{pH}$ seduhan teh yang dihasilkan. Persentase penggunaan teh kering sebesar $5 \%$ dapat memberikan seduhan teh dengan $\mathrm{pH}$ paling rendah atau dengan rasa yang paling asam. Semakin tinggi persentase penggunaan teh kering akan meningkatkan jumlah senyawa fenolik yang ikut terlarut dalam seduhan teh. Komponen fenol ini dapat mengalami oksidasi menghasilkan senyawa asam. Menurut Réblová (2012), asam-asam fenolik akan menunjukkan penurunan seiring dengan meningkatnya suhu.

\section{Karakteristik dan Kandungan Fungsional Seduhan Teh Daun Bidara}

Secara umum perlakuan metode pengeringan serta persentase penggunaan teh kering memberikan pengaruh signifikan pada seluruh kandungan senyawa polifenol yang diuji pada penelitian ini serta aktivitas dari antioksidan seduhan teh daun bidara disajikan dalam Tabel 3.

Tabel 3. Senyawa Fungsional dan Aktivitas Antioksidan Seduhan Teh Daun Bidara

\begin{tabular}{cccccc}
\hline Sampel & $\begin{array}{c}\text { Tot. Fenol } \\
(\mathbf{m g} / \mathbf{L})\end{array}$ & $\begin{array}{c}\text { Tot. Flavonoid } \\
(\mathbf{m g} / \mathbf{L})\end{array}$ & Tannin $(\mathbf{m g} / \mathbf{L})$ & $\begin{array}{c}\text { Akt. } \\
\text { Antioksidan } \\
(\%)\end{array}$ \\
\hline \multirow{3}{*}{ Kabinet } & $1 \%$ & $69.89 \pm 1.08^{\dagger}$ & $61.85 \pm 2.31^{\dagger}$ & $15.53 \pm 0.30^{\dagger}$ & $29.21 \pm 0.69^{\mathrm{g}}$ \\
& $3 \%$ & $200.36 \pm 8.14^{\mathrm{e}}$ & $176.72 \pm 4.24^{\mathrm{e}}$ & $49.44 \pm 0.65^{\mathrm{d}}$ & $39.65 \pm 1.88^{\mathrm{e}}$ \\
& $5 \%$ & $322.22 \pm 10.16^{\mathrm{c}}$ & $336.97 \pm 4.24^{\mathrm{c}}$ & $81.28 \pm 1.64^{\mathrm{b}}$ & $46.94 \pm 0.79^{\mathrm{c}}$ \\
\hline \multirow{3}{*}{ Sangrai } & $1 \%$ & $77.42 \pm 2.84^{\dagger}$ & $67.23 \pm 5.33^{\dagger}$ & $15.71 \pm 0.62^{\dagger}$ & $31.64 \pm 0.40^{\dagger}$ \\
& $3 \%$ & $255.91 \pm 5.99^{\mathrm{d}}$ & $188.26 \pm 9.74^{\mathrm{e}}$ & $49.79 \pm 1.11^{\mathrm{d}}$ & $42.52 \pm 0.44^{\mathrm{d}}$ \\
& $5 \%$ & $379.57 \pm 3.88^{\mathrm{b}}$ & $355.44 \pm 4.24^{\mathrm{b}}$ & $82.14 \pm 1.05^{\mathrm{b}}$ & $49.80 \pm 0.90^{\mathrm{b}}$ \\
\hline \multirow{2}{*}{ Sinar } & $1 \%$ & $86.02 \pm 2.84^{\mathrm{f}}$ & $75.44 \pm 5.77^{\dagger}$ & $19.21 \pm 0.70 \mathrm{e}$ & $37.47 \pm 0.78^{\mathrm{e}}$ \\
Matahari & $3 \%$ & $280.65 \pm 11.97^{\mathrm{d}}$ & $248.51 \pm 3.87^{\mathrm{d}}$ & $58.70 \pm 1.81^{\mathrm{c}}$ & $47.21 \pm 0.52^{\mathrm{c}}$ \\
& $5 \%$ & $444.44 \pm 15.07^{\mathrm{a}}$ & $424.92 \pm 4.28^{\mathrm{a}}$ & $88.06 \pm 1.29^{\mathrm{a}}$ & $54.74 \pm 0.47^{\mathrm{a}}$ \\
\hline
\end{tabular}

Keterangan: $\quad$ 1. Data disertai dengan standar deviasi hasil dari rerata 3 kali ulangan.

2. Angka disertai huruf berbeda menandakan perbedaan nyata $\alpha=0.05$ ). 


\subsection{Total Fenol}

Hasil analisis total fenol menunjukkan sampel seduhan teh bidara yang dihasilkan mengandung fenol sebesar 69.89 hingga $444.44 \mathrm{mg} / \mathrm{L}$. Seduhan teh yang dibuat dengan menggunakan metode pengeringan sinar matahari memiliki nilai total fenol paling banyak daripada metode pengeringan sangrai maupun kabinet. Suhu yang diguanakan pada pengeringan metode panas matahari relatif tidak tinggi yaitu hanya sekitar $27^{\circ} \mathrm{C}$ yang menyebabkan senyawa fenolik dalam daun tidak banyak mengalami kerusakan akibat panas. Menurut Harjanti et al., (2003) komponen fenolik dapat mengalami kerusakan akibat panas pada suhu yang relatif tinggi yaitu diatas $85^{\circ} \mathrm{C}$. Beberapa komponen fenolik dapat rusak dan ikut terbuang selama pengeringan, terutama beberapa komponen fenolik larut air yang memiliki ikatan $\mathrm{OH}$ pada strukturnya.

Persentase penggunaan teh kering yang semakin banyak akan meningkatkan kandungan fenol dalam seduhan teh yang dibuat. Persentase penggunaan teh daun bidara kering $5 \%$ dapat memberikan hasil seduhan teh dengan jumlah total fenol paling banyak dibandingkan persentase teh kering lain yang digunakan. Menurut Shabri \& Rohdiana (2016) senyawa polifenol mudah larut dengan air, sehingga senyawa ini mampu larut dalam air saat diseduh menggunakan air hangat. Teori tersebut sesuai dan mendukung penelitian ini, dimana dengan semakin banyak persentase penggunaan teh kering yang dipilih maka seduhan teh akan mangandung senyawa polifenol yang semakin banyak terlarut didalamnya.

\subsection{Total Flavonoid}

Hasil analisis total flavonoid sampel seduhan teh bidara yang dibuat pada penelitian kali ini didapatkan sebesar 61.85 hingga $424.92 \mathrm{mg} / \mathrm{L}$. Seduhan teh hasil proses pengeringan sinar matahari memiliki kandungan total flavonoid paling tinggi dibandingkan jenis pengeringan lainya. Suhu yang digunakan pada pengeringan menggunakan bantuan matahari relatif rendah dibandingkan kedua metode pengeringan lainnya, sehingga panas yang diberikan tidak merusak senyawa flavonoid dalam daun. Sharma et al. (2015), menyatakan bahwa komponen flavonoid dapat naik ataupun turun akibat suhu. Pemanasan suhu tinggi merusak struktur flavonoid yang menyebabkan kerusakan fungsi alamiah dari flavonoid. Sedangkan suhu optimal dapat menurunkan kadar air yang berakibat pada kenaikan kadar flavonoid dalam sampel. Jenis flavonoid juga mempengaruhi jumlahnya dalam bahan. Beberapa senyawa flavonoid bersifat termolabil seperti katekin akan sangay mudah mengalami kerusakan akibat suhu tinggi saat dikeringkan.

Persentase penggunaan teh kering yang semakin banyak akan menghasilkan seduhan teh dengan kandungan total flavonoid yang semakin banyak. Persentase penggunaan teh kering sebesar $5 \%$ pada penelitian ini memiliki nilai flavonoid tertinggi pada seduhan teh dihasilkan dibandingkan metode pengeringan lainnya. Semakin banyak persentase penggunaan teh kering akan meningkatkan banyaknya senyawa flavonoid yang ikut terlarut pada air seduhan terutama flavonoid larut air seperti katekin. Anjarsari, I, R (2016) menyatakan bahwa katekin adalah komponen tak berwarna, memiliki rasa sepat atau pahit, bersifat larut air, dan membentuk rasa khas pada teh bidara yang dihasilkan.

\subsection{Kadar Tanin}

Seduhan teh bidara pada penelitian ini memiliki jumlah kandungan tanin sebesar 15.54-88.06 mg/L. Seduhan teh bidara hasil proses pengeringan metode sinar matahari memiliki kandungan tanin tertinggi dibandingkan hasil metode pengeringan yang lain. Pengeringan dengan bantuan panas sinar matahari adalah salah satu metode pengeringan yang menggunakan temperatur relatif rendah dibandingkan kabinet dan sangrai. Pengeringan ini tidak akan merusak senyawa tanin pada daun bidara. Dewi, R, A, (2011) menyatakan bahwa tanin dapat mengalami kerusakan akibat panas pada temperatur tinggi. Beberapa tanin pada bahan pangan dapat rusak strukrurmya serta fungsinya dan akan turun jumlahnya pada suhu diatas $80^{\circ} \mathrm{C}$. 
Persentase penggunaan teh kering dengan jumlah semakin meningkat akan menyebabkan peningkatan kadar tanin yang terlarut pada seduhan teh yang dibuat. Persentase penggunaan teh kering sebesar 5\% memiliki kadar tanin paling tinggi jika dibandingkan persentase $1 \%$ dan 3\%. Penggunaan teh kering dalam jumlah tinggi dapat meningkatkan tanin yang terlarut dalam seduhan teh. Khasnabis et al., (2015) menyatakan bahwa tanin adalah golongan polifenol yang memiliki sifat larut dalam air yang sangat memungkinkan larut pada saat proses penyeduhan teh dilakukan.

\subsection{Aktivitas Antioksidan}

Sampel seduhan teh bidara pada penelitian ini memiliki aktivitas antioksidan sebeasar $29.21 \%$ hingga $54.4 \%$. Teh bidara yang dibuat dengan pengeringan menggunakan bantuan panas sinar matahari memiliki nilai aktivitas antioksidan tertinggi jika dibandingkan teh bidara hasil metode pengeringan sangrai ataupun kabinet. Data tersebut dapat dikarenakan penggunaan pengeringan dengan metode bantuan sinar matahari cenderung menggunakan temperatur yang rendah. Pengerngan temperatur rendah tersebut mampu menjaga komponen-komponen yang dapat berperan sebagai antioksidan dari kerusakan. Berdasarkan penelitian Taufik et al., (2016) terkait pengaruh suhu pengeringan pada pengeringan teh daun murbai hitam dengan respon aktivitas antioksidan. Peningkatan temperatur pengering yang digunakan dapat menyebabkan penurunan aktivitas antioksidan pada teh daun murbai hitam. Jacobo-Velázquez \& Cisneros-Zevallos (2009) menjelaskan bahwa sebagian besar komponen polifenol mampu berperan sebagai pemberi kontribusi utama dalam menangkal oksidasi pada bahan pangan. Senyawa fenolik mampu berperan sebagai anti oksidasi atau yang sering disebut sebagai antioksidan, sehingga jika jumlahnya tinggi dalam bahan pangan maka dapat diperkirakan jika bahan pangan tersebut kaya akan antioksidan dan aktivitasnya. Senyawa fenolik dapat mengalami degradasi akibat pemanasan. Beberapa ikatan fenolik akan mengalami kerusakan sehingga senyawa fenolik tidak memiliki fungsi yang baik (Harjanti et al., 2003).

Persentase penggunaan teh kering yang semakin banyak dalam pebuatan teh daun bidara akan meningkatkan aktivitas antioksidan. Persentase penggunaan teh kering sebesar $5 \%$ pada penelitian ini mampu menghasilkan aktivitas antioksidan paling tinggi pada sampel teh yang diuji. Penggunaan teh kering dengan persentase yang semakin banyak mampu meningkatkan kelarutan polifenol dalam seduhan teh dan akan berperan sebagai antioksidan. Rohdiana (2015) menyatakan bahwa komponen fenolik seperti katekin pada produk teh memiliki peran yang tidak kalah penting sebagai anti-oksidan yang berfungsi menangkal radikal-radikal bebas penyebab penyakit degeneratif yang ada di dalam tubuh. Hasil penelitian menunjukan bahwa persentase penggunaan teh kering sebesar $5 \%$ memiliki seduhan teh dengan total fenol tertinggi dibandingkan jumlah lainnya, sehingga didapatkan bahwa seduhan teh tersebut juga memiliki aktivitas antioksidan paling tinggi.

\section{Uji Hedonik Seduhan Teh Daun Bidara}

Uji hedonik dilaksanakan pada 9 sampel seduhan teh daun bidara kepada 40 panelis tidak terlatih dengan respon berupa 3 parameter seperti pada Gambar 1.

\subsection{Uji Hedonik Parameter Aroma}

Hasil pengujian hedonik pada penelitian ini memperlihatkan bahwa kesukaan panelis pada parameter aroma seduhan teh daun bidara di penelitian ini sebesar $2.85-3.43$. Hasil uji ANOVA menunjukkan bahwa persentase penggunaan teh kering memberikan pengaruh signifikan pada nilai kesukaan panelis pada parameter aroma yang disajikan. Namun uji ANOVA juga menunjukkan bahwa perlakuan metode pengeringan tidak memberikan pengaruh signifikan pada nilai kesukaan panelis pada parameter aroma sampel yang disajikan.

Persentase penggunaan teh kering daun bisara yang semakin banyak akan mampu meningkatkan nilai kesukaan panelis pada parameter aroma sampel yang disajikan. Hasil tersebut dapat didorong dengan semakin banyaknya penggunaan teh kering yang dipilih. 
Semakin banyak penggunaan teh kering maka komponen volatil atau senyawa aromatis penghasil aroma pada teh akan ikut terlarut dalam seduhan teh bidara. Towaha \& Balittri (2013) menyatakan bahwa selama proses pemanasan pada pengeringan daun teh, beberapa protein akan mengalami kerusakan atau denaturasi dalam daun. Hal ini menyebabkan asam amino menjadi lebih bebas dari dalam protein, sehingga mampu berikatan dan berinteraksi dengan komponen lain untuk membentuk senyawa kompleks aromatis yang memberikan aroma khas pada teh saat diseduh. Beberapa komponen polifenol seperti katekin mampu berinteraksi dengan asam amino saat pemanasan menggunakan temperatur tinggi dan mampu membentuk senyawa aldehide yang akan membentuk aroma pada teh.

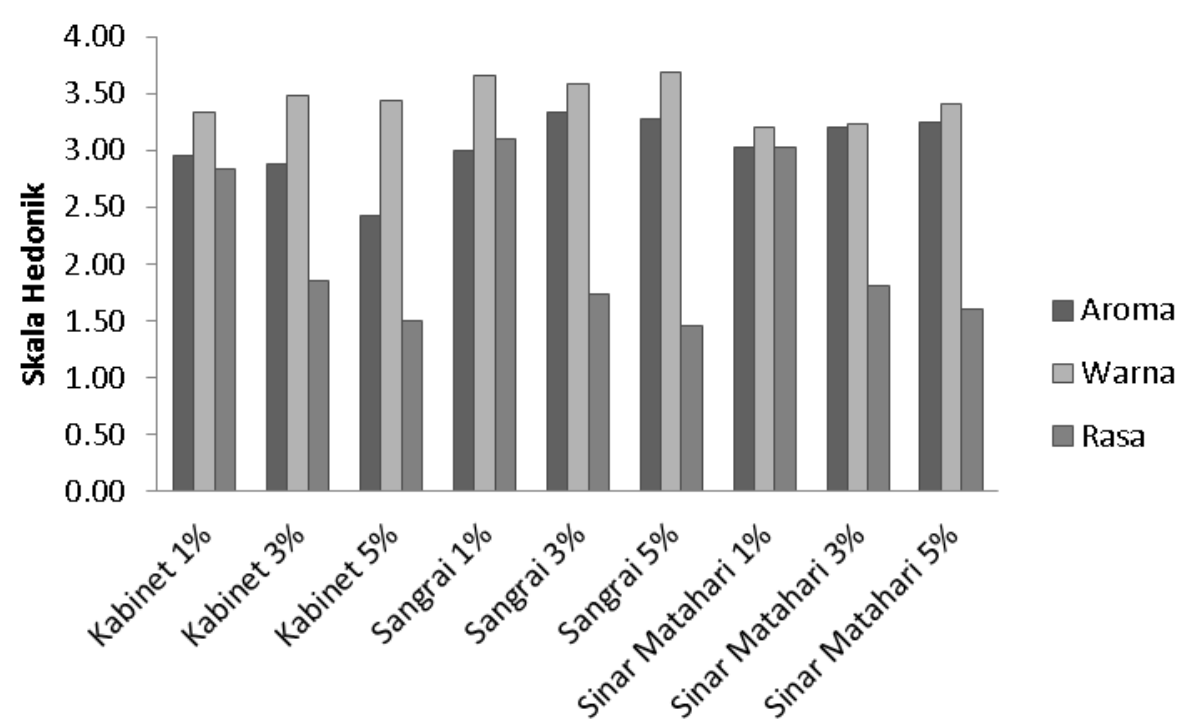

Gambar 1. Rerata Kesukaan Panelis terhadap Karakteristik Organoleptik Seduhan Teh Daun Bidara

\subsection{Uji Hedonik Parameter Warna}

Hasil pengujian hedonik pada penelitian ini menunjukkan bahwa penliaian panelis pada parameter kesukaan warna sampel seduhan teh daun bidara di penelitian ini sebesar 3.15 - 3.75. Hasil uji ANOVA menunjukkan bahwa kedua meliputi metode pengeringan dan persentase penggunaan teh kering berpengaruh signifikan pada nilai parameter warna sampel. Seduhan teh daun bidara hasil pengeringan sangrai memiliki warna seduhan teh yang paling menarik dan cenderung memiliki nilai tingkat kesukaan warna paling tinggi dibandingkan yang lain dari panelis. Menurut Anjarsari, I, R (2016) warna seduhan pada teh akan sangat dipengaruhi komponen penyusunnya. Beberapa komponen warna dapat terbentuk akibat hasil oksidasi polifenol seperti theaflavin dan thearubigin. Warna teh daun bidara juga sangat dipengaruhi oleh degradasi klorofil yang terjadi selama pemanasan dan penyeduhan. Klorofil yang terdegradasi akan menghasilkan feofitin sebagai senyawa derivat dari klorofil yang berwarna kuning kecoklatan (Schwartz et al., 2017).

Persentase penggunaan teh kering sebesar $5 \%$ pada penyeduhan sampel teh bidara paling disukai oleh panelis dibandingkan persentase lain yang digunakan. Hasil ditunjukkan dari skor penilaian panelis yang tinggi, dan hal tersebut dapat disebabkan karena dengan banyaknya penggunaan teh kering yang diseduh maka akan meningkatkan komponen pembentuk warna yang ikut terlarut dalam air seduhan seperti thearubigin, theaflavin, hingga klorofil. Teori lain yang dapat mendukung hasil ini yaitu dengan banyaknya teh kering yang diseduh maka akan meningkatkan jumlah klorofil yang terdegradasi akibat panas menjadi komponen derivatisasi, seperti fefitin yang disebabkan oleh hilangnya ion $\mathrm{Mg}^{2+}$ pada cincin forfirin selama pemanasan. Hasil dari degradasi klorofil akan menurunkan intensitas warna 
hijau dari klorofil dan perlahan akan berubah menjadi kuning kecoklatan yang merupakan warna dari feofitin (Ferruzzi \& Blakeslee, 2007). Warna teh yang semakin coklat gelap lebih disukai dibandingkan teh dengan warna cerah oleh panelis.

\subsection{Uji Hedonik Parameter Rasa}

Hasil pengujian hedonik pada penelitian ini menunjukkan jika nilai skor kesukaan panelis pada parameter rasa seduhan teh bidara sebesar 1.25 - 3.10. Hasil uji ANOVA didapatkan bahwa kedua perlakuan yaitu metode pengeringan dan persentase penggunaan teh kering berpengaruh signifikan pada skor kesukaan panelis terhadap parameter rasa sampel yang disajikan. Seduhan teh hasil pengeringan bantuan panas matahari memiliki nilai kesukaan rasa yang lebih tinggi dibandingkan pengering kabinet, namun nilai skor rasanya tidak berbeda nyata dengan sampel teh yang dibuat dengan proses pengeringan sangrai. Hasil tersebut dapat dikarenakan pada teh hasil pengeringan panas matahari banyak terkandung komponen fenolik yang bisa memberikan rasa pada seduhan teh daun bidara. Umumnya senyawa polifenol akan memberikan rasa sepat serta pahit yang khas pada teh. Rohdiana (2015) menyatakan bahwa beberapa komponen yang dapat membentuk rasa dalam pembuatan teh yaitu senyawa-senyawa fenolik diantaranya tanin, saponnin, dan alkaloid yang menghasilkan rasa sepat. Senyawa lain yang dapat membentuk rasa pahit dalam teh yaitu kafein.

Persentase penggunaan teh kering yang semakin banyak akan menurunkan nilai skor kesukaan panelis pada rasa teh bidara yang disajikan. Hal tersebut dapat dikarenakan adanya rasa yang tidak disukai panelis yaitu pahit dan rasa sepet yang tinggi apabila teh kering yang diseduh dalam jumlah banyak. Penyeduhan teh kering dengan jumlah banyual juga akan melarutkan banyak komponen polifenol yang membentuk rasa yang tidak disukai oleh panelis. Hasil penelitian dari El-Ishaq, A, R, O \& Nangere, Z, (2016) juga menunjukkan secara kualitatif bahwa senyawa-senyawa fenolik seperti tanin, flavonoid dalam bentuk katekin, saponin, hingga alkaloid terkandung dalam daun bidara segar dan dapat memberikan rasa pahit.

\section{SIMPULAN}

Perlakuan jenis pengeringan memberikan pengaruh signifikan pada respon kadar air, warna, $\mathrm{pH}$, kandungan senyawa fungsional seperti flavonoid, fenol, tanin serta aktivitas antioksidan, kemudian parameter warna dan rasa pada uji organoleptik teh bidara. Persentase penggunaan teh kering pada penenlitian ini juga memberikan pengaruh signifikan pada parameter warna, $\mathrm{pH}$, seluruh kandungan senyawa fungsional serta aktivitas antioksidan, dan semua parameter uji organoleptik yang diuji pada penelitian ini. Hasil pengujian metode Zeleny manghasilkan jika seduhan teh bidara hasil pengeringan dengan metode bantuan panas sinar matahari dengan persentase penggunaan teh kering sebesar $5 \%$ merupakan teh terbaik yang dihasilkan pada penelitian ini.

\section{DAFTAR PUSTAKA}

AACC. (2000). Approved methods of the american association of cereal chemists, 10 th 4 ed. The Association: St. Paul, MN.

Anjarsari, I, R, D. (2016). Katekin teh Indonesia : prospek dan manfaatnya. Kultivasi, 15(2). https://doi.org/10.24198/kultivasi.v15i2.11871

Association of Official Analytical Chemists. (1995). Official Methods of Analysis of AOAC International (P. Cunniff (ed.); 16th editi). Association of Official Analytical Chemists.

Blois, M. S. (1958). Antioxidant Determinations by the Use of a Stable Free Radical. Nature, 181(4617), 1199-1200. https://doi.org/10.1038/1811199a0

Dewi, R, A, S. (2011). Uji Kualitatif dan Kuantitatif Tanin pada Kulit Batang dan Daun Belimbing Wuluh (Averrhoa Bilimbi L) Secara Spektrofotometri Menggunakan Pereaksi Biru Prusia. Universitas Surabaya. 
El-Ishaq, A, R, O, A., \& Nangere, Z, A. (2016). Proximate and Phytochemical Analysis of Ziziphus mauritania Lam Leaves. Frontiers in Biomedical Sciences, 1(2), 45-49.

Ferruzzi, M. G., \& Blakeslee, J. (2007). Digestion, absorption, and cancer preventative activity of dietary chlorophyll derivatives. Nutrition Research, 27(1), 1-12. https://doi.org/10.1016/j.nutres.2006.12.003

Food and Agriculture Organization of the United Nations. (2015). World tea production and trade: current and future development.

Harjanti, R. S., Purwanti, E., \& Sarto. (2003). Zat Warna Kunyit (Kurkumin) sebagai Indikator Titrasi Asam Basa. Prossiding Seminar Nasional Teknik Kimia Indonesia.

Jacobo-Velázquez, D. A., \& Cisneros-Zevallos, L. (2009). Correlations of Antioxidant Activity against Phenolic Content Revisited: A New Approach in Data Analysis for Food and Medicinal Plants. Journal of Food Science, 74(9), R107-R113. https://doi.org/10.1111/j.1750-3841.2009.01352.x

Khasnabis, J., Rai, C., \& Roy, A. (2015). Determination of tannin content by tritametric method from different types of tea. Journal of Chemical and Pharmaceutical Research, $7(6), 238-242$.

Matthäus, B. (2002). Antioxidant Activity of Extracts Obtained from Residues of Different Oilseeds. Journal of Agricultural and Food Chemistry, 50(12), 3444-3452. https://doi.org/10.1021/jf011440s

Orwa, C., Mutua, A., Kindt, R., Jamnadass, R., \& Anthony, S. (2009). Ziziphus mauritiana. Agroforestree Database: a tree reference and selection guide version 4.0. World Agroforestry Centre, Kenya.

Réblová, Z. (2012). Effect of temperature on the antioxidant activity of phenolic acids. Czech Journal of Food Sciences, 30(No. 2), 171-175. https://doi.org/10.17221/57/2011-CJFS

Rohdiana, D. (2015). Teh: Proses, Karakteristik \& Komponen Fungsionalnya. FOODREVIEW INDONESIA, 10(8), 34-37.

Schwartz, S. J., Cooperstone, J. L., Cichon, M. J., Joachim, H. V., \& Monica, G. (2017). Colorants Fennema's Food Chemistry ed Damodaran S, Parkin L K. Boca Raton: CRC Press, 10.

Shabri, S., \& Maulana, H. (2017). Synthesis and isolation of theaflavin from fresh tea leaves as bioactive ingredient of antioxidant supplements. Jurnal Penelitian Teh Dan Kina, 20(1), 1-12. https://doi.org/10.22302/pptk.jur.jptk.v20i1.120

Shabri, S., \& Rohdiana, D. (2016). Optimization and characterization of green tea polyphenol extract from various solvents. Jurnal Penelitian Teh Dan Kina, 19(1). https://doi.org/10.22302/pptk.jur.jptk.v19i1.82

Sharma, K., Ko, E. Y., Assefa, A. D., Ha, S., Nile, S. H., Lee, E. T., \& Park, S. W. (2015). Temperature-dependent studies on the total phenolics, flavonoids, antioxidant activities, and sugar content in six onion varieties. Journal of Food and Drug Analysis, 23(2), 243-252. https://doi.org/10.1016/j.jfda.2014.10.005

Taufik, Y., Widiantara, T., \& Garnida, Y. (2016). The effect of drying temperature on the antioxidant activity of black mulberry leaf tea (Morus nigra). Rasayan Journal Chemistry, 9(4), 889-895.

Towaha, J., \& Balittri. (2013). Kandungan senyawa kimia pada daun teh (Camelia sinensis). Warta Penelitian Dan Pengembangan Tanaman Industri, 19(3), 12-16.

Yahia, Y., Benabderrahim, M. A., Tlili, N., Bagues, M., \& Nagaz, K. (2020). Bioactive compounds, antioxidant and antimicrobial activities of extracts from different plant parts of two Ziziphus Mill. species. PLOS ONE, 15(5), 1-16. https://doi.org/10.1371/journal.pone.0232599

Yulianto, M. E., Arirvibowo, D., Arifan, F., Kusumayanti, H., Nugraheni, F. S., \& Senen. (2006). Mass transfer model of the steaming process of oxidase enzyme inactivation in green tea processing. Jurnal Gema Teknologi. Jurnal Gema Teknologi, 15(2).

Zeleny, M. (1982). Multiple Criteria Decision Making (McGraw-Hill Series in Quantitative Methods for Management). McGraw-Hill. 